\title{
Bioremediation of Petroleum Hydrocarbons Using Acinetobacter sp. SCYY-5 Isolated from Contaminated Oil Sludge: Strategy and Effectiveness Study
}

\author{
Yiyun Cai ${ }^{1,2,3}$, Runkai Wang ${ }^{1,2, *}$, Pinhua Rao ${ }^{1}$, Baichun Wu ${ }^{3, *}$, Lili Yan ${ }^{1}$, Lijiang Hu ${ }^{1,4}$, Sangsook Park ${ }^{5}$, \\ Moonhee Ryu ${ }^{6}$ and Xiaoya Zhou ${ }^{1}$ \\ 1 School of Chemistry and Chemical Engineering, Shanghai University of Engineering Science, \\ Shanghai 201620, China; m040118137@sues.edu.cn (Y.C.); raopinhua@sues.edu.cn (P.R.); \\ liliyan@sues.edu.cn (L.Y.); 15868218094@126.com (L.H.); M040119306@sues.edu.cn (X.Z.) \\ 2 College of Civil Engineering, Kashgar University, Kashgar 844006, China \\ 3 State Key Laboratory of Petroleum Pollution Control, Beijing 102206, China \\ 4 Anji Guoqian Environmental Technology Co., Ltd., Huzhou 313000, China \\ 5 Department of Environmental Engineering, Sunchon National University, 255 Jungang-ro, Suncheon, \\ Jeonnam 57922, Korea; ssp@scnu.ac.kr \\ 6 Division of Biotechnology, College of Environmental and Bioresource Sciences, Chonbuk National University, \\ Iksan 570-752, Korea; Ryumh@jbnu.ac.kr \\ * Correspondence: wangrunkai@sues.edu.cn (R.W.); wu-baichun@cnpc.com.cn (B.W.); \\ Tel.: +86-021-67791217 (R.W.); +86-010-80169539 (B.W.)
}

Citation: Cai, Y.; Wang, R.; Rao, P.; Wu, B.; Yan, L.; Hu, L.; Park, S.; Ryu, M.; Zhou, X. Bioremediation of Petroleum Hydrocarbons Using Acinetobacter sp. SCYY-5 Isolated from Contaminated Oil Sludge: Strategy and Effectiveness Study. Int. J. Environ. Res. Public Health 2021, 18, 819. https://doi.org/10.3390/ ijerph18020819

Received: 30 November 2020

Accepted: 13 January 2021

Published: 19 January 2021

Publisher's Note: MDPI stays neutral with regard to jurisdictional claims in published maps and institutional affiliations.

Copyright: (c) 2021 by the authors. Licensee MDPI, Basel, Switzerland. This article is an open access article distributed under the terms and conditions of the Creative Commons Attribution (CC BY) license (https:// creativecommons.org/licenses/by/ $4.0 /)$.

\begin{abstract}
Biodegradation has been considered as an ideal technique for total petroleum hydrocarbon (TPH) contamination, but its efficiency is limited by its application in the field. Herein, an original TPH-degrading strain, SCYY-5, was isolated from contaminated oil sludge and identified as Acinetobacter sp. by $16 \mathrm{~S}$ rDNA sequence analysis. The biological function of the isolate was investigated by heavy metal tolerance, carbon, and nitrogen source and degradation tests. To enhance its biodegradation efficiency, the response surface methodology (RSM) based on a function model was adopted to investigate and optimize the strategy of microbial and environmental variables for TPH removal. Furthermore, the performance of the system increased to $79.94 \%$ with the further addition of extra nutrients, suggesting that the RSM and added nutrients increased the activity of bacteria to meet the needs of the co-metabolism matrix during growth or degradation. These results verified that it is feasible to adopt the optimal strategy of combining bioremediation with RSM to improve the biodegradation efficiency, for contaminated oil sludge.
\end{abstract}

Keywords: biodegradation; bioremediation; TPH; Acinetobacter sp.; $16 \mathrm{~S}$ rDNA; response surface methodology (RSM)

\section{Introduction}

The oil industry inevitably produces a large amount of dense solid waste called oil sludge, which is produced during various production, transportation, and refining processes [1]. Oil sludge is exposed to biological and abiotic processes over time, such as limited microbial degradation, auto-oxidation, and volatilization, resulting in different degrees of pollution [2,3]. The pollutants in oil sludge are usually divided into inorganic pollutants such as copper, chromium and cadmium, and organic pollutants such as saturated hydrocarbons, polycyclic aromatic hydrocarbons, asphaltenes, and so on [4]. Total petroleum hydrocarbon (TPH), ranging from C15 to C36 or more, take a large fraction of the content of oil sludge [5]. Since the toxicity of oil sludge at high concentrations poses a potential risk to the environment and human health [6], it has already been listed in the US Environmental Protection Agency.

Various traditional treatment techniques for oil sludge have been proposed, like solvent extraction, chemical oxidation, landfill, natural attenuation, etc. Compared with these 
costly and time-consuming technologies, biodegradation is a reliable and relatively costeffective technique to solve oil pollution $[7,8]$. Several studies have reported the ability of multiple organisms isolated from polluted environments, including molds, bacteria, fungi, and algae, to use petroleum hydrocarbons as their sole source of carbon and energy $[9,10]$. More than 70 genera and 200 species of microorganisms have been found to degrade petroleum hydrocarbons. The majority of petroleum hydrocarbon degraders are bacteria, such as Pseudomonas [11], Acinetobacter [12], Flavobacterium [13], and Corynebacterium [14], which can oxidize petroleum components through metabolic activities and be used for biological treatment of oil-contaminated areas. Many previous studies have focused on the infection and drug resistance of Acinetobacter, including studies on Acinetobacter degradation of petroleum hydrocarbons. With the continuous occurrence of oil spills worldwide, its degradation efficiency needs to be improved. Hence, it is of great significance to study and optimize the biodegradation efficiency of Acinetobacter.

However, bioremediation is affected by multiple variables, and it is unreliable and time-consuming to analyze, compare, and optimize the process with classical methods. As a statistical analysis method, response surface methodology (RSM) is used to overcome these shortcomings. RSM is usually developed to analyze the relationship between one or more response variables to obtain the optimal response [15,16]. The Box-Behnken Design (BBD) is one of the experimental designs of RSM. As an independent three-level factor quadratic design, it requires fewer runs and is more efficient than other designs [17]. The advantage of BBD is that it can identify potential interactions between the variables, which help to avoid experiments under extreme conditions. Although RSM has been successfully applied in many fields, such as emulsion liquid membrane processes [18], fermentation conditions [19], milk processing wastewater [20], etc., there are few reports on the use of RSM to study and optimize the removal of TPH by microbial and environmental variables. Thus, using RSM to degrade TPH has become a hot topic.

The purpose of this study was to isolate and identify the petroleum hydrocarbondegrading bacteria in oil sludge and to solve the problem of limited efficiency of the biodegradation technique. Heavy metal tolerance, carbon, and nitrogen sources and degradation tests were used to evaluate the biological function of the isolates and their potential to degrade petroleum hydrocarbons. RSM was used to establish a quadratic equation model to optimize the isolated bacteria and environmental factors: temperature (A), $\mathrm{pH}(\mathrm{B})$, and $\mathrm{NaCl}$ concentration (C), and to select an optimum condition. The optimal condition and extra nutrients further promoted the bioremediation of TPH.

\section{Materials and Methods}

\subsection{Chemicals and Media}

Oil sludge samples, containing $38,236.62 \mathrm{mg} \mathrm{kg}^{-1}$ of n-alkanes, were kindly provided by the State Key Laboratory of Petroleum Pollution Control of China. The oil sludge is in a viscous solid-state, which forms agglomerates at low temperatures, and precipitates black oil at high temperatures. The sludge was stored in a refrigerator at $4{ }^{\circ} \mathrm{C}$ before the biodegradability test. Clear-up oil sludge is performed by a microwave resolution method (CJ/T221-2005) and its heavy metal elements are detected by the ICP-MS method. The average concentrations of some heavy metals in oil sludge are shown in Table 1. The ingredients of minimal salt medium (MSM, analytical grade) were as follows: $0.67 \mathrm{~g} \mathrm{~L}^{-1} \mathrm{NH}_{4} \mathrm{Cl}, 0.8 \mathrm{~g} \mathrm{~L}^{-1} \mathrm{~K}_{2} \mathrm{HPO}_{4}, 0.4 \mathrm{~g} \mathrm{~L}^{-1} \mathrm{KH}_{2} \mathrm{PO}_{4}, 0.2 \mathrm{~g} \mathrm{~L}^{-1} \mathrm{NaCl}, 0.05 \mathrm{~g} \mathrm{~L}^{-1}$ $\mathrm{CaCl}_{2}, 0.05 \mathrm{~g} \mathrm{~L}^{-1} \mathrm{MgSO}_{4}, 0.05 \mathrm{~g} \mathrm{~L}^{-1} \mathrm{FeSO}_{4} \cdot 7 \mathrm{H}_{2} \mathrm{O}, 0.01 \mathrm{~g} \mathrm{~L}^{-1} \mathrm{MnSO}_{4} \cdot \mathrm{H}_{2} \mathrm{O}$, and $0.01 \mathrm{~g} \mathrm{~L}^{-1}$ $\mathrm{Na}_{2} \mathrm{MoO}_{4} \cdot 2 \mathrm{H}_{2} \mathrm{O}$ [21]. The lysogeny broth (LB) medium was composed of $3 \mathrm{~g} \mathrm{~L}^{-1}$ beef extract, $10 \mathrm{~g} \mathrm{~L}^{-1}$ peptone and $5 \mathrm{~g} \mathrm{~L}^{-1} \mathrm{NaCl}$. The nitrogen-free medium was composed of $3.84 \mathrm{~g} \mathrm{~L}^{-1}$ citrate, $0.8 \mathrm{~g} \mathrm{~L}^{-1} \mathrm{~K}_{2} \mathrm{HPO}_{4}, 0.4 \mathrm{~g} \mathrm{~L}^{-1} \mathrm{KH}_{2} \mathrm{PO}_{4}, 0.2 \mathrm{~g} \mathrm{~L}^{-1} \mathrm{NaCl}, 0.05 \mathrm{~g} \mathrm{~L}^{-1}$ $\mathrm{CaCl}_{2}, 0.05 \mathrm{~g} \mathrm{~L}^{-1} \mathrm{MgSO}_{4}, 0.05 \mathrm{~g} \mathrm{~L}^{-1} \mathrm{FeSO}_{4} \cdot 7 \mathrm{H}_{2} \mathrm{O}, 0.01 \mathrm{~g} \mathrm{~L}^{-1} \mathrm{MnSO}_{4} \cdot \mathrm{H}_{2} \mathrm{O}$, and $0.01 \mathrm{~g} \mathrm{~L}^{-1}$ $\mathrm{Na}_{2} \mathrm{MoO}_{4} \cdot 2 \mathrm{H}_{2} \mathrm{O}$. All media in this study were sterilized at $121^{\circ} \mathrm{C}$ for $20 \mathrm{~min}$ before use. The $\mathrm{pH}$ of the diverse media utilized in this study was 7 . The standard solution UST127- 
TPH Mix (17 n-alkanes, $2000 \mathrm{mg} \mathrm{L}^{-1}$ ) was purchased from Sigma-Aldrich. The data in this study were averaged from triplicate experiments.

Table 1. The average concentrations of some heavy metals in oily sludge.

\begin{tabular}{cc}
\hline Heavy Metals & Concentration $\left.\mathbf{~} \mathbf{m g} \mathbf{~ k g}^{\mathbf{1}}\right)$ \\
\hline $\mathrm{Cu}$ & $2116.76 \pm 9.52$ \\
$\mathrm{Cd}$ & $210.93 \pm 2.37$ \\
$\mathrm{~Pb}$ & $69.85 \pm 2.25$ \\
$\mathrm{Cr}$ & $120.20 \pm 5.04$ \\
$\mathrm{Zn}$ & $1672.44 \pm 0.75$ \\
\hline
\end{tabular}

\subsection{Enrichment and Isolation of the Strains}

The strains from the source material, oil sludge, were enriched in a $250 \mathrm{~mL}$ conical flask containing $100 \mathrm{~mL}$ of MSM medium with $1 \mathrm{~g}$ of oil for seven days. The strains from the above-enriched solution were isolated, using a gradient dilution and spread plate technique. Then, different single colonies were selected and streaked on an LB plate. After multiple isolation and purification, the SCYY-5 with growth activity reaching the peak value at the soonest was screened based on the growth curve of the isolated strains.

\subsection{TPH Biodegradation Ability of SCYY-5}

To determine the degradation ability of the isolate to TPH, the isolate was cultured at $30{ }^{\circ} \mathrm{C}$, and $150 \mathrm{rpm}$ for $18 \mathrm{~h}\left(\mathrm{OD}_{600}: 1\right)$ in the $\mathrm{LB}$ medium. Then, the bacterial solution was placed in a $50 \mathrm{~mL}$ centrifuge tube at $2500 \times \mathrm{g}$ for $10 \mathrm{~min}$. The centrifuged cells were washed with MSM and centrifuged for 2 to 3 times to be reserved. About $20 \mathrm{~mL}$ of MSM was supplemented with $1 \%(\mathrm{w} / \mathrm{v})$ oil sludge in a series of $50 \mathrm{~mL}$ conical flasks, which were employed for biodegradation tests. The inoculation amount of bacterial liquid was $10 \%$. Then, they were cultured at $30^{\circ} \mathrm{C}$, and $150 \mathrm{rpm}$ for 10 days. The concentration of TPH in oil sludge was determined by gas chromatography (GC 2060, Shanghai Acute Instrument Co., LTD., Shanghai, China) every two days, and the TPH biodegradation efficiency was calculated.

The standard solution UST127-TPH Mix (17 n-alkanes, $\left.2000 \mathrm{mg} \mathrm{L}^{-1}\right)$ was used to make the standard curve $\left(10,20,50,100,200 \mathrm{mg} \mathrm{L}^{-1}\right)$. GC was used to analyze the degradation of TPH by the isolate after dichloromethane extraction. About $2 \mu \mathrm{L}$ of the organic phase was injected into the GC 2060 instrument equipped with an FID detector and HP-5 capillary column $(30 \mathrm{~m} \times 0.32 \mathrm{~mm} \times 0.25 \mu \mathrm{m}$, J\&W Scientific, Folsom, CA, USA). The analysis conditions for GC were as follows: detector temperature, $310{ }^{\circ} \mathrm{C}$; injector temperature, $280^{\circ} \mathrm{C}$; and carrier gas rate, $1.95 \mathrm{~mL} / \mathrm{min}$. The column temperature was kept at $50{ }^{\circ} \mathrm{C}$ for $1 \mathrm{~min}$ and was then ramped at $30^{\circ} \mathrm{C} / \mathrm{min}$ to $310^{\circ} \mathrm{C}$ for $10 \mathrm{~min}$ in split mode (1:7).

\subsection{Physiological Characterisation of the Isolated Strain}

The metal salts used to prepare for $\mathrm{Cu}^{2+}, \mathrm{Cd}^{2+}, \mathrm{Pb}^{2+}, \mathrm{Cr}^{3+}, \mathrm{Zn}^{2+}\left(4000 \mathrm{mg} \mathrm{L}{ }^{-1}, 100 \mathrm{~mL}\right)$ stock solutions were $1.5125 \mathrm{~g} \mathrm{Cu}\left(\mathrm{NO}_{3}\right)_{2} \cdot 3 \mathrm{H}_{2} \mathrm{O}\left(241.60 \mathrm{~g} \mathrm{~mol}^{-1}\right), 1.11 \mathrm{~g} \mathrm{Cd}\left(\mathrm{NO}_{3}\right)_{2} \cdot 4 \mathrm{H}_{2} \mathrm{O}$ $\left(308.41 \mathrm{~g} \mathrm{~mol}^{-1}\right), 0.6396 \mathrm{~g} \mathrm{~Pb}\left(\mathrm{NO}_{3}\right)_{2}\left(331.20 \mathrm{~g} \mathrm{~mol}^{-1}\right), 3.0769 \mathrm{~g} \mathrm{Cr}^{-}\left(\mathrm{NO}_{3}\right)_{3} \cdot 9 \mathrm{H}_{2} \mathrm{O}\left(400.00 \mathrm{~g} \mathrm{~mol}^{-1}\right)$, and $1.8277 \mathrm{~g} \mathrm{Zn}\left(\mathrm{NO}_{3}\right)_{2} \cdot 6 \mathrm{H}_{2} \mathrm{O}\left(297.48 \mathrm{~g} \mathrm{~mol}^{-1}\right)$ (analytical grade) [22]. Then, the stock solutions were diluted to $0,4,10,20,30,40,60,100,150,200,250,300,400$, and $500 \mathrm{mg} \mathrm{L}^{-1}$ in the LB medium. The strain SCYY-5 was cultured in the LB medium with five different metal ions: $\mathrm{Cu}^{2+}, \mathrm{Cd}^{2+}, \mathrm{Pb}^{2+}, \mathrm{Cr}^{3+}$, and $\mathrm{Zn}^{2+}$ at $30^{\circ} \mathrm{C}$, and $150 \mathrm{rpm}$ to evaluate its tolerance to heavy metals. The colony numbers of bacteria were tested under the same concentration of different heavy metals by a plate counting method at log phase $(18 \mathrm{~h})$.

To investigate the effects of different carbon and nitrogen sources on the growth of strain, the carbon source studies were conducted using MSM as the essential medium with an equimolar concentration $(20 \mathrm{mM})$ of fructose $\left(3.60 \mathrm{~g} \mathrm{~L}^{-1}\right)$, glucose $\left(3.60 \mathrm{~g} \mathrm{~L}^{-1}\right)$, sucrose $\left(6.85 \mathrm{~g} \mathrm{~L}^{-1}\right)$, lactose $\left(6.85 \mathrm{~g} \mathrm{~L}^{-1}\right)$, soluble starch $\left(6.85 \mathrm{~g} \mathrm{~L}^{-1}\right)$ and citrate $\left(3.84 \mathrm{~g} \mathrm{~L}^{-1}\right)$. The other ingredients remained unchanged [23]. They were cultured at $30^{\circ} \mathrm{C}$, and $150 \mathrm{rpm}$ 
for nearly $40 \mathrm{~h}$, and bacterial growth was monitored by turbidity measurements by measuring the absorbance of the bacterial solution at $600 \mathrm{~nm}[24,25]$. The nitrogen source studies were carried out in a nitrogen-free medium, with the same equimolar concentration $(20 \mathrm{mM})$ of the extra nitrogen source $\left(2.80 \mathrm{~g} \mathrm{~L}^{-1}\right.$ yeast extract, $2.94 \mathrm{~g} \mathrm{~L}^{-1} \mathrm{~L}$-glutamic acid, $2.02 \mathrm{~g} \mathrm{~L}^{-1}$ potassium nitrate, $2.64 \mathrm{~g} \mathrm{~L}^{-1}$ ammonium sulfate, $1.07 \mathrm{~g} \mathrm{~L}^{-1}$ ammonium chloride).

\subsection{Predictive Optimisation of TPH Degradation Based on RSM}

The optimization procedure for TPH removal was conducted using BBD in Designexpert with physical-chemical parameters: temperature (A), $\mathrm{pH}(\mathrm{B})$, and $\mathrm{NaCl}$ concentration (C) as variables. Each aspect in the design has three different levels $(-1,0$ and 1); Table 2 shows the list for each factor. A total of 17 experiments were performed in this design with TPH removal efficiency as the response. This includes 12 design diameters and 5 replication center point diameters, which were used to rule out experimental errors and fit the quadratic equation models. The statistical analysis (ANOVA) and plot response surfaces were performed using the Design-Expert 8.0 (Stat-Ease, Inc., Minneapolis, MN, USA) statistical software. Multiple regression and function models were used to evaluate the experimental data, and an F test was used to analyze the significance of the regression [17]. The following second-order polynomial equation was used to fit the experimental results and determine the relevant model terms.

$$
Y=\beta_{0}+\sum \beta_{i} X_{i}+\sum \beta_{i i} X_{i}^{2}+\sum \beta_{i j} X_{i} X_{j}
$$

where $Y$ is the predicted response; $\beta_{0}, \beta_{i}, \beta_{i i}$, and $\beta_{i j}$ are fixed regression coefficients of the model; and $X_{i}$ and $X_{j}$ represent independent variables.

Table 2. Summary of experimental factors and design.

\begin{tabular}{ccccc}
\hline Factor & Unit & $\mathbf{- 1}$ & $\mathbf{0}$ & $\mathbf{1}$ \\
\hline (A) Temperature & ${ }^{\circ} \mathrm{C}$ & 20 & 30 & 40 \\
(B) $\mathrm{pH}$ & $/$ & 5 & 7 & 9 \\
(C) $\mathrm{NaCl}$ concentration & $\mathrm{g} \mathrm{L}^{-1}$ & 0 & 10 & 20 \\
\hline
\end{tabular}

Meanwhile, to further improve the biodegradation efficiency, carbon and nitrogen sources were added for the biodegradation tests under the optimal conditions of RSM. According to the above physiological characteristics, the carbon and nitrogen sources with the most significant influence on the growth rate of the bacteria were selected. No additional nutrients were added under optimal conditions in (1) the control group; and the other group was (2) optimum condition $+\mathrm{C} \& N$ sources. The other experimental conditions were consistent with the above.

\subsection{Identification of the SCYY-5 Strain}

The bacterial genomic DNA was extracted using the AxyPrep DNA isolation kit. The universal bacterial 16S rDNA primers, 27F (5'-AGAGTTTGATCCTGGCTCAG-3') and 1492R (5'-CTACGGCTACCTTGTTACGA-3') were used to amplify bacterial 16S rDNA [26]. The PCR product of purified strains was subjected to DNA sequencing by the sequencer ABI3730-XL. The NCBI Blast program was used to compare the spliced sequence files with the data in the NCBI 16S database (https:/ / www.ncbi.nlm.nih.gov). The species information with the greatest similarity to the sequences to be tested was obtained, which was the identification result. Phylogenetic trees for 16S rDNA were built using MEGA 6.0 software (Arizona State University, Tempe, AZ, USA).

\section{Results}

\subsection{Isolation and Identification of the SCYY-5 Strain}

The SCYY-5 strain with the highest growth activity was isolated from the oil sludge, which was selected from multiple isolates after multiple isolation and purification. The 
colonies cultured on the LB solid medium for two days were translucent, pale yellow, round, and moist with shiny edges. The isolate was identified by DNA sequencing. The sequence of the SCYY-5 strain was searched in an NCBI Blast, and phylogenetic analysis based on $16 \mathrm{~S}$ rDNA gene sequences indicated that the SCYY-5 strain belongs to the genus Acinetobacter sp., as shown in Figure 1.

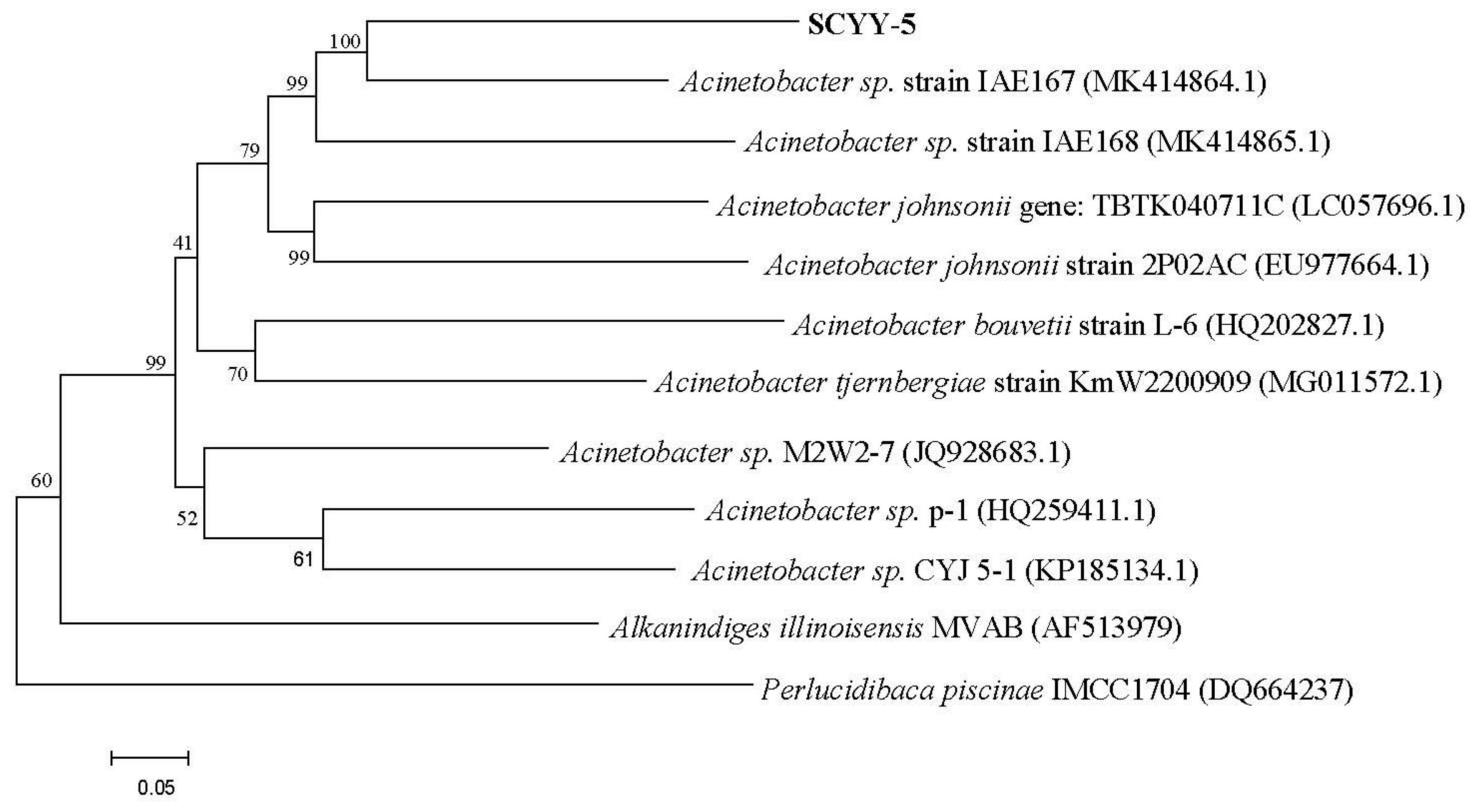

Figure 1. Phylogenetic trees of Acinetobacter sp. SCYY-5. Phylogenetic trees were constructed based on the 16S rDNA gene sequences (1241 bp) using the neighbor joining method. Phylogeny test used bootstrap method with 1000 replications.

\subsection{Biodegradation Ability of TPH by the Isolated Strain}

The concentration of $13 \mathrm{n}$-alkanes detected in the oil sludge was $38,236.62 \mathrm{mg} \mathrm{kg}^{-1}$. The degradation ability of Acinetobacter sp. SCYY-5 to n-alkanes was preliminarily determined after 10 days of culture. The degradation efficiency reached $69.17 \%$ on the tenth day. The content of $13 \mathrm{n}$-alkanes decreased from $38,236.62 \mathrm{mg} \mathrm{kg}^{-1}$ to $11,788.35 \mathrm{mg} \mathrm{kg}^{-1}$ after the treatment (Table S1). It was proven that this strain can degrade TPH, but further optimization and exploration were needed.

Figure 2 shows the GC profiles of TPH removal by Acinetobacter sp. SCYY-5. It can be seen that C14 and C28 were degraded (Table S1), and the concentration of each component decreased to some extent. Those with a moderate length (C9-C16) were lessened by $82.00 \%$, and the long-chain alkanes (C17-C34) were spoiled by $61.76 \%$. Interestingly, some nalkanes such as C30 have a higher concentration than the initial concentration on the 10th day of culture.

\subsection{Physiological Characterization of the Isolated Strain}

The tolerance of Acinetobacter sp. SCYY-5 to $\mathrm{Cr}^{3+}, \mathrm{Cu}^{2+}, \mathrm{Pb}^{2+}$, and $\mathrm{Zn}^{2+}$ was slightly higher than that of $\mathrm{Cd}^{2+}$ (Figure 3). The growth of the strain was promoted when $\mathrm{Cu}^{2+}$ was less than $30 \mathrm{mg} \mathrm{L}^{-1}$, and the colony numbers further increased. Bacterial growth was also promoted when $\mathrm{Cr}^{3+}$ was less than $10 \mathrm{mg} \mathrm{L}^{-1} \cdot \mathrm{Pb}^{2+}, \mathrm{Zn}^{2+}$, and $\mathrm{Cd}^{2+}$ had different degrees of inhibition on the isolate, and the cell survival in $\mathrm{Cd}^{2+}$ decreased to less than $10 \%$ at $60 \mathrm{mg} \mathrm{L}^{-1}$. The general order of resistance of Acinetobacter sp. SCYY-5 to heavy metals was as follows: $\mathrm{Cd}^{2+}<\mathrm{Zn}^{2+}<\mathrm{Pb}^{2+}=\mathrm{Cr}^{3+}<\mathrm{Cu}^{2+}$. The maximal concentration tolerated was $100 \mathrm{mg} \mathrm{L}^{-1}$ for $\mathrm{Cd}^{2+}, 250 \mathrm{mg} \mathrm{L}^{-1}$ for $\mathrm{Zn}^{2+}, 300 \mathrm{mg} \mathrm{L}^{-1}$ for $\mathrm{Pb}^{2+}$ and $\mathrm{Cr}^{3+}$ and $400 \mathrm{mg} \mathrm{L}^{-1}$ for $\mathrm{Cu}^{2+}$. Although most heavy metals can damage the cell membrane and disrupt nutrient transport, $\mathrm{Cu}^{2+}$ was the most tolerated metal by the isolate and $\mathrm{Cd}^{2+}$ was the least tolerated. 


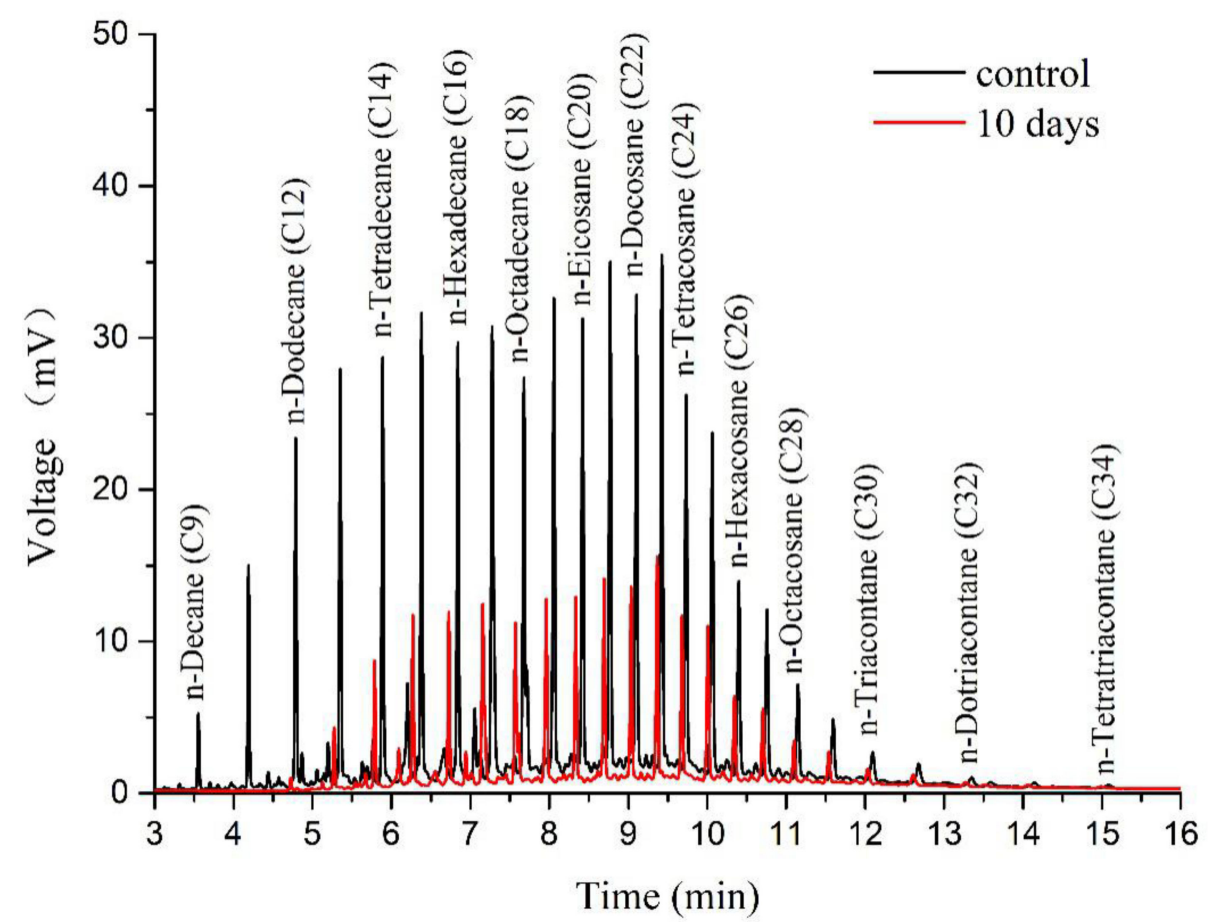

Figure 2. The comparison of GC profiles of TPH removal by Acinetobacter sp.: a control group and 10 days.

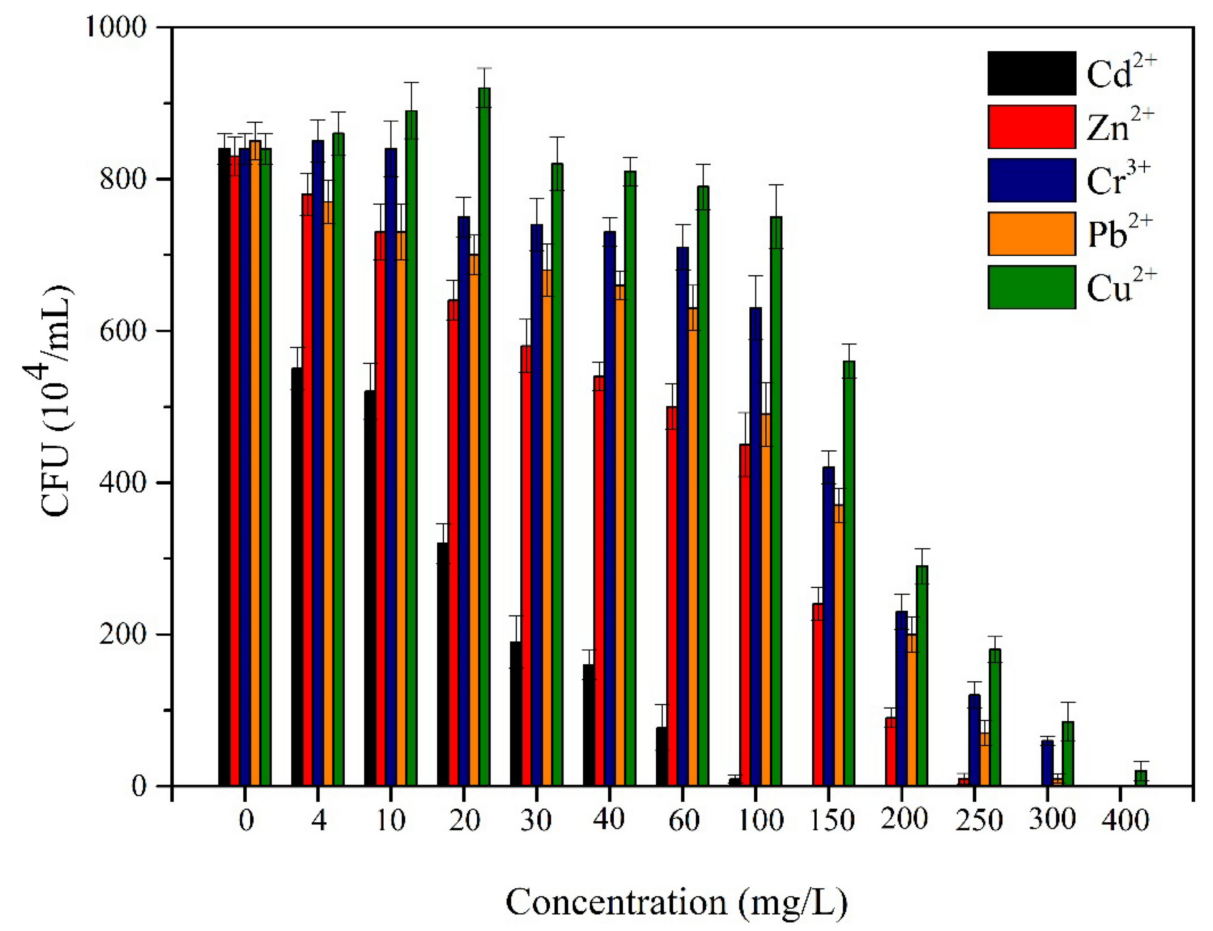

Figure 3. The tolerance of Acinetobacter sp. SCYY-5 to 5 heavy metals: $\mathrm{Cu}^{2+}, \mathrm{Cd}^{2+}, \mathrm{Zn}^{2+}, \mathrm{Pb}^{2+}$, and $\mathrm{Cr}^{3+}$. The general order of resistance of Acinetobacter sp. SCYY-5 to heavy metals is as follows: $\mathrm{Cd}^{2+}<\mathrm{Zn}^{2+}<\mathrm{Pb}^{2+}=\mathrm{Cr}^{3+}<\mathrm{Cu}^{2+}$.

The carbon sources, such as glucose, sucrose, fructose, lactose, soluble starch, and citrate, were used as nutrients for bacterial growth. As shown in Figure $4 \mathrm{a}$, the strain grew very slowly in the MSM medium compared with other conditions containing carbon sources. It can be considered that the presence of extra carbon sources promoted the overall growth of Acinetobacter sp. SCYY-5. This indicates that the carbon sources were utilized 
during the growth of the strain. Compared with the blank control group, it shows that the preferred carbon sources by Acinetobacter sp. SCYY- 5 can be arranged in a sequence, as follows: sucrose $<$ lactose $<$ fructose $<$ glucose $<$ soluble starch $<$ citrate. The maximum cell growth $\left(\mathrm{OD}_{600}\right)$ was 1.085 under the condition of citrate as a carbon source.

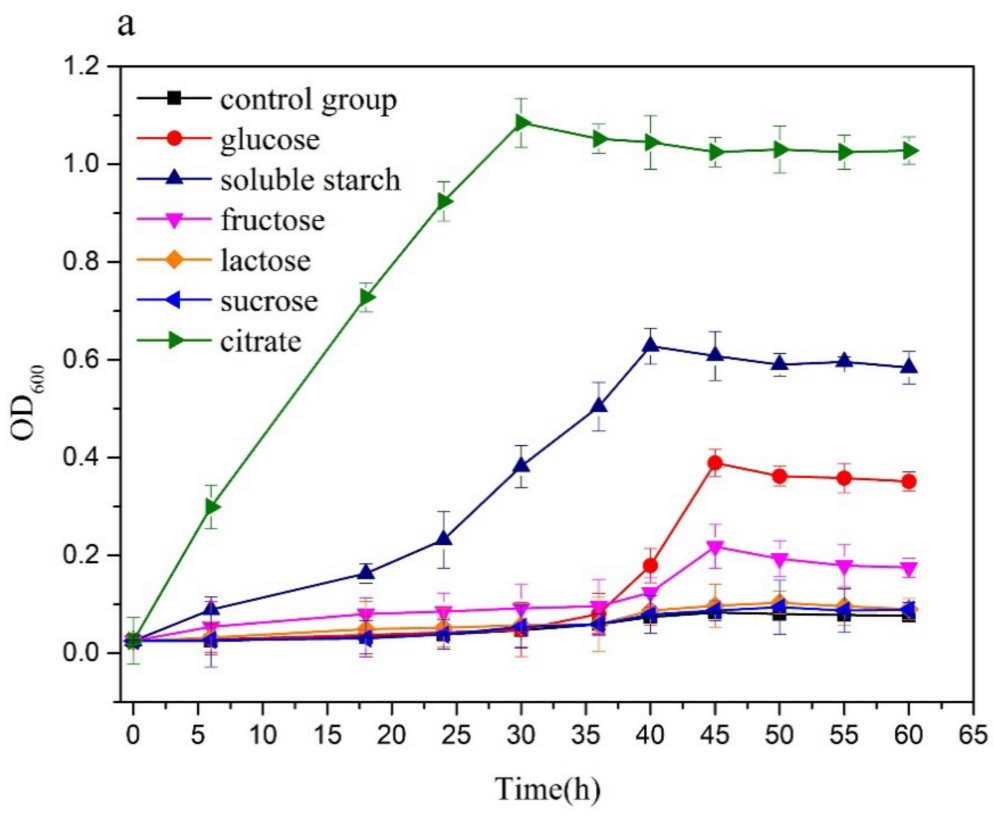

b

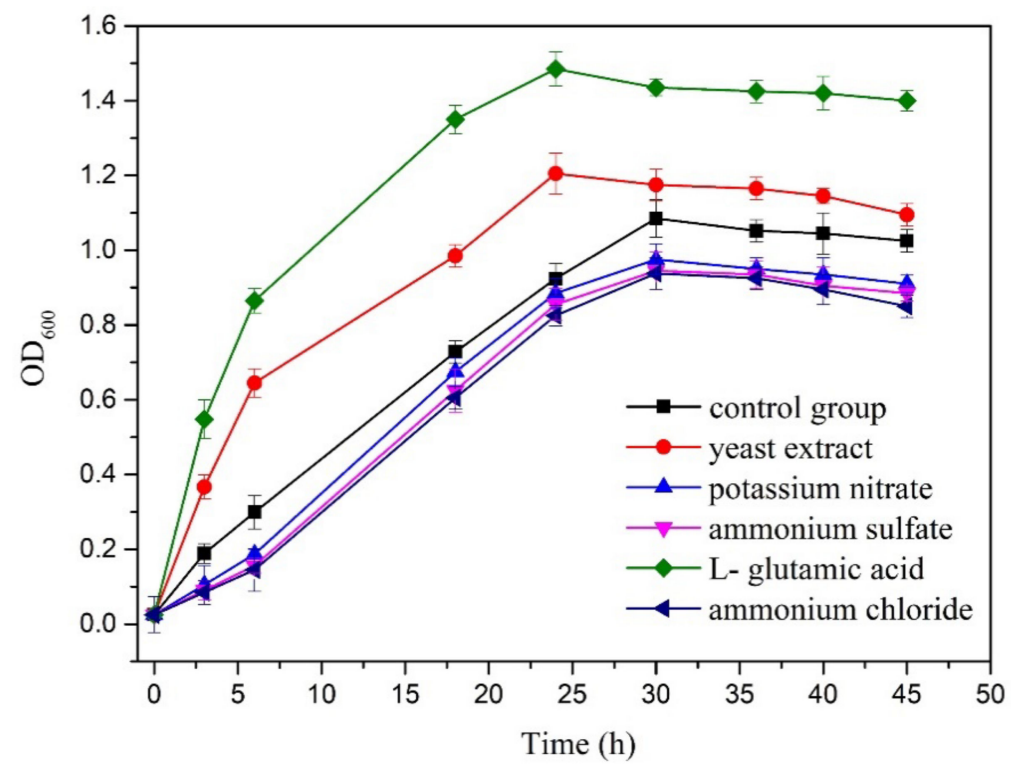

Figure 4. Growth profile of Acinetobacter sp. SCYY-5 (a) carbon sources, (b) nitrogen sources.

Similarly, the result in Figure $4 \mathrm{~b}$ shows the preferred nitrogen sources of the isolate in the following order: ammonium chloride $<$ ammonium sulfate $<$ potassium nitrate $<$ yeast extract $<$ L-glutamic acid. The addition of inorganic nitrogen sources did not promote the growth of the strain. The utilization rate of organic nitrogen by the isolate was significantly higher than that of inorganic nitrogen, and the maximum cell growth $\left(\mathrm{OD}_{600}\right)$ was 1.485 , with L-glutamic acid as the nitrogen source.

\subsection{Predictive Optimisation of TPH Degradation Based on RSM}

The experimental data were fitted by multiple regression in Design-Expert 8.0. The response surface test designs with the actual and predicted values obtained are shown in 
Table 3. The quadratic polynomial regression model equation of variables and response values obtained from the analysis is as follows:

$$
\mathrm{Y}=64.03+0.32 \mathrm{~A}+6.16 \mathrm{~B}-0.13 \mathrm{C}+3.17 \mathrm{AB}-0.28 \mathrm{AC}-0.70 \mathrm{BC}-14.40 \mathrm{~A}^{2}-5.36 \mathrm{~B}^{2}-11.19 \mathrm{C}^{2}
$$

where $\mathrm{Y}$ stands for TPH removal, $\mathrm{A}$ is the temperature, $\mathrm{B}$ is the $\mathrm{pH}$ and $\mathrm{C}$ is the $\mathrm{NaCl}$ concentration.

Table 3. Box-Behnken design scheme with the observed and predicted response for TPH removal.

\begin{tabular}{|c|c|c|c|c|c|}
\hline Run & $\begin{array}{c}\text { (A) Temperature } \\
\left({ }^{\circ} \mathrm{C}\right)\end{array}$ & (B) $\mathrm{pH}$ & $\begin{array}{l}\text { (C) } \mathrm{NaCl} \\
\left(\mathrm{g} \mathrm{L}^{-1}\right)\end{array}$ & $\begin{array}{c}\text { TPH Removal } \\
\text { (\%) }\end{array}$ & $\begin{array}{l}\text { Predicted } \\
\text { Value }(\%)\end{array}$ \\
\hline 1 & 30 & 7 & 10 & 67.07 & 64.03 \\
\hline 2 & 40 & 7 & 0 & 42.25 & 39.17 \\
\hline 3 & 30 & 7 & 10 & 64.87 & 64.03 \\
\hline 4 & 30 & 9 & 20 & 60.91 & 54.20 \\
\hline 5 & 20 & 7 & 0 & 41.23 & 37.98 \\
\hline 6 & 30 & 9 & 0 & 53.46 & 53.08 \\
\hline 7 & 30 & 7 & 10 & 53.51 & 64.03 \\
\hline 8 & 30 & 5 & 20 & 40.11 & 40.49 \\
\hline 9 & 20 & 7 & 20 & 35.20 & 38.27 \\
\hline 10 & 20 & 5 & 10 & 44.44 & 40.98 \\
\hline 11 & 40 & 9 & 10 & 50.46 & 53.93 \\
\hline 12 & 30 & 5 & 0 & 35.44 & 42.15 \\
\hline 13 & 30 & 7 & 10 & 67.97 & 64.03 \\
\hline 14 & 20 & 9 & 10 & 43.32 & 46.95 \\
\hline 15 & 40 & 7 & 20 & 35.11 & 38.35 \\
\hline 16 & 30 & 7 & 10 & 66.75 & 64.03 \\
\hline 17 & 40 & 5 & 10 & 38.88 & 35.26 \\
\hline
\end{tabular}

To verify the reliability of the function model based on the response surface, ANOVA was done to determine the influence of various factors on the system response and their interaction. The results are shown in Table $4, p=0.0248<0.05$ indicates that the model has statistical significance. Lack of fit $(p=0.3081>0.05)$ is not significant, and the residual caused by random error indicates that the model fits well. Figure S1 shows the different diagnostic plots to ensure that the residuals were plotted against the predicted value. As shown in Figure S1a, the reasonable match between the standardized residuals and normal probability percentage confirms that the statistical assumptions are suitable to analyze the data. Figure S1b presents no obvious pattern, as the observed runs are randomly distributed in the range of residuals $(-3,3)$, confirming the adequacy of the model. The F-value is 4.84 , which shows that the system response can be explained by the regression equation [27]. The fact can prove that if $R^{2}$ is closer to 1 , the stronger the prediction ability of the model [28]. Hence, the correlation coefficient $R^{2}$ is 0.8616 , and the adjusted $R^{2}$ is 0.7596, which proves that the model fits well with the actual situation [29].

The Design-Expert 8.0 software was used to draw the response surface curve and contour plots for the model. The three-dimensional (3D) response surface and two-dimensional (2D) contour plots reflect the influence and interaction between any two factors of temperature (A), $\mathrm{pH}(\mathrm{B})$, and $\mathrm{NaCl}$ concentration (C) on TPH removal, as shown in Figure 5. For instance, as shown in Figure $5 \mathrm{a}, \mathrm{b}$, when the initial $\mathrm{pH}$ (temperature) value is constant, the TPH removal increases initially and then decreases with the increase in temperature $(\mathrm{pH})$. The purpose of 17 groups of experiments designed by RSM is to adjust the concentration of each factor to provide an effective limiting range for BBD. The experimental results are consistent with the significance of data analysis results in Table 4. Therefore, we consider it valid that the actual value of each factor is zero. 
Table 4. ANOVA analysis of the quadratic model.

\begin{tabular}{cccccc}
\hline Parameter & Sum of Squares & Degree of Freedom & Mean Square & F-Value & $p>$ F \\
\hline Model & 2017.66 & 9 & 224.18 & 4.84 & 0.0248 \\
A & 0.79 & 1 & 0.79 & 0.017 & 0.8995 \\
B & 303.64 & 1 & 303.64 & 6.56 & 0.0375 \\
C & 0.14 & 1 & 0.14 & 0.003 & 0.9578 \\
AB & 40.32 & 1 & 40.32 & 0.87 & 0.3818 \\
AC & 0.31 & 1 & 0.31 & 0.0066 & 0.9375 \\
BC & 1.93 & 1 & 1.93 & 0.042 & 0.8439 \\
A $^{2}$ & 872.66 & 1 & 872.66 & 18.85 & 0.0034 \\
$B^{2}$ & 121.00 & 1 & 121.00 & 2.61 & 0.1500 \\
$C^{2}$ & 527.54 & 1 & 527.54 & 11.39 & 0.0118 \\
Residual & 324.15 & 7 & 46.31 & & \\
Lack of Fit & 180.54 & 3 & 60.18 & 1.68 & 0.3081 \\
Pure Error & 143.61 & 4 & 35.90 & & Insignificant \\
Cor Total & 2341.81 & 16 & & & \\
$\mathrm{R}^{2}=0.8616$ & Adj $\mathrm{R}^{2}=0.7596$ & & & & \\
\hline
\end{tabular}
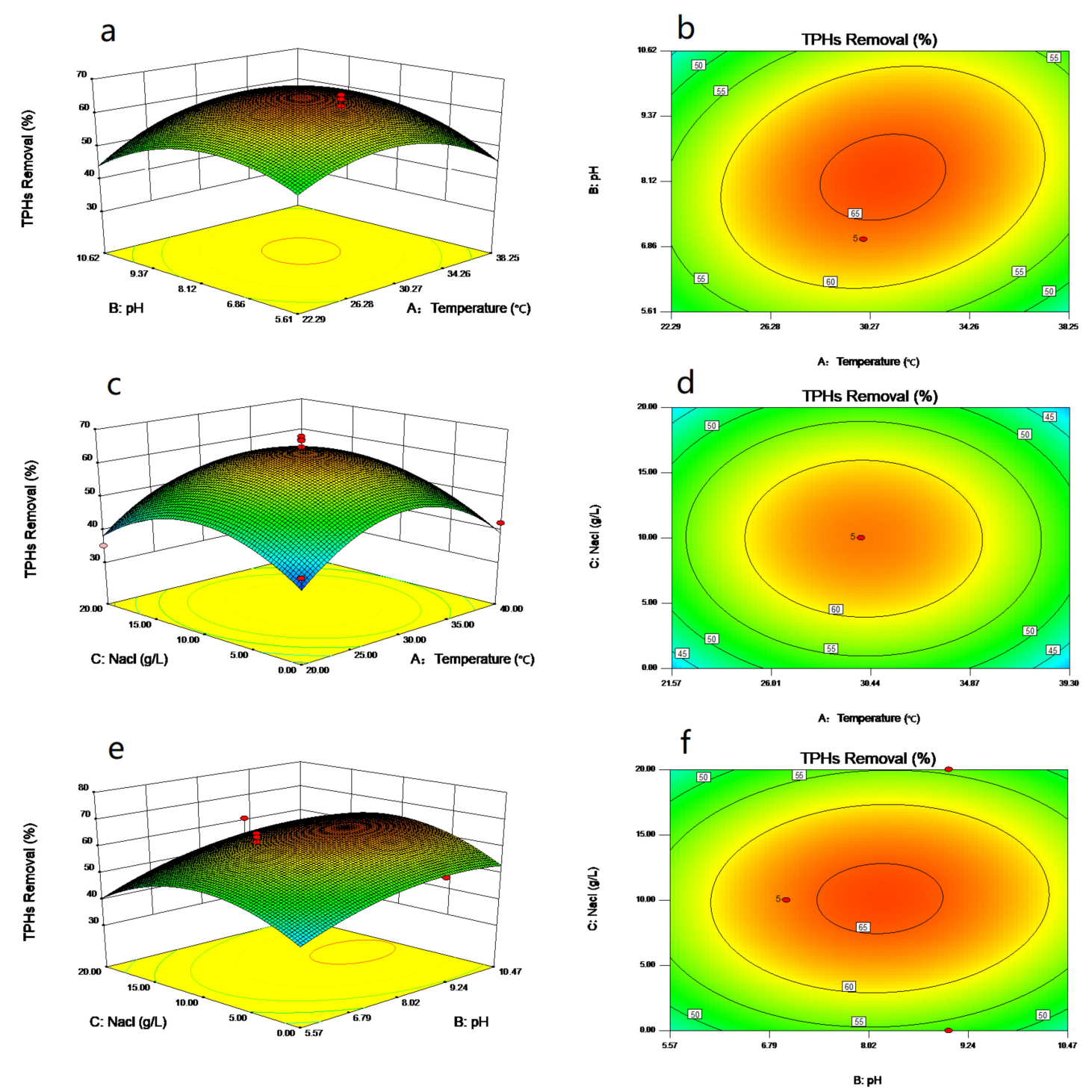

Figure 5. RSM response surface and contour plots for TPH removal as a function of the variables: (a,b) Temperature (A) and $\mathrm{pH}(\mathrm{B}),(\mathbf{c}, \mathbf{d})$ Temperature (A) and $\mathrm{NaCl}(\mathrm{C}),(\mathbf{e}, \mathbf{f}) \mathrm{pH}(\mathrm{B})$ and $\mathrm{NaCl}(\mathrm{C})$. 
The optimal condition (temperature $=30.77^{\circ} \mathrm{C}, \mathrm{pH}=8.20, \mathrm{NaCl}=10.12 \mathrm{~g} \mathrm{~L}^{-1}$ ) based on RSM was predicted. The predicted value of TPH removal under the optimal condition was $65.89 \%$, the actual experimental value was $70.29 \%$ and the residual was $4.4 \%$. It was found that TPH removal with carbon and nitrogen sources (citrate and L-glutamic acid) under the optimal condition could reach $79.94 \%$. The degradation efficiency of hydrocarbons increased by $9.65 \%$. Besides, compared with the degradation efficiency of other bacteria on hydrocarbons, the SCYY-5 strain in this study had a significantly stronger degradation ability in a short time (Table 5), which can be directly applied to the treatment of pollutants.

Table 5. Comparison of degradation period and degradation efficiency of hydrocarbons by different strains.

\begin{tabular}{cccc}
\hline Species & $\begin{array}{c}\text { Degradation } \\
\text { Period (Day) }\end{array}$ & $\begin{array}{c}\text { Degradation } \\
\text { Efficiency (\%) }\end{array}$ & References \\
\hline Pseudomonas sp. CS-2 & 7 & 41 & {$[30]$} \\
Rhodococcus sp. PG-39 & 7 & 48 & {$[30]$} \\
Bacillus sp. E3 & 21 & 63 & {$[31]$} \\
Acinetobacter sp. XM-02 & 10 & 74.32 & {$[32]$} \\
Acinetobacter sp. SCYY-5 & 10 & 79.94 & This study \\
\hline
\end{tabular}

\section{Discussion}

There are reports that have proposed that using bioremediation to solve the pollution problem of oil sludge is feasible $[33,34]$, while the biodegradation efficiency has limited its application in the field. Many factors such as temperature, $\mathrm{pH}$, salinity, etc., will have a specific influence. Therefore, this study aimed to adopt the optimal strategy of combining bioremediation with RSM to solve the problem of biodegradation efficiency.

The pollutants in oil sludge are usually divided into inorganic pollutants (copper, chromium, cadmium, salts, etc.) and organic pollutants (TPHs, PAHs, etc.), which will greatly affect the growth and activity of microorganisms. Hence, we first discussed the isolation and identification of the strain and the effect of various heavy metals on its growth. In this study, the SCYY-5 strain isolated from oil sludge provided by the State Key Laboratory of Petroleum Pollution Control was identified as Acinetobacter sp. Based on $16 \mathrm{~S}$ rDNA gene sequences. According to the results of heavy metal tolerance experiments, the general order of resistance of Acinetobacter sp. SCYY-5 to heavy metals is as follows: $\mathrm{Cd}^{2+}<\mathrm{Zn}^{2+}<\mathrm{Pb}^{2+}=\mathrm{Cr}^{3+}<\mathrm{Cu}^{2+}$. The tolerance of Acinetobacter sp. To metal ions has been reported. Cai et al. (2019) [35] isolated an Acinetobacter sp. Strain from an electroplating wastewater treatment, which was resistant to $\mathrm{Cu}^{2+}$ and $\mathrm{Ni}^{2+}$, while Zakaria et al. (2007) [23] isolated the Acinetobacter haemolyticus strain resistant to $\mathrm{Zn}^{2+}$ and $\mathrm{Cr}^{6+}$. Compared with these reported bacteria growing in other environments, the isolates may not have the highest tolerance to a single heavy metal, but shows good resistance to $\mathrm{Cr}^{3+}, \mathrm{Cu}^{2+}, \mathrm{Pb}^{2+}$, $\mathrm{Zn}^{2+}$ but not to $\mathrm{Cd}^{2+}$. This can be thought of as its solubility and affinity for potential complexing agents such as organic compounds [23], and the tolerance of the isolates to $\mathrm{Cu}^{2+}$ was higher than the strain of Cai et al. (2019) [35], with a cell survival rate of more than $40 \%$ at $200 \mathrm{mg} \mathrm{L}^{-1}$. We used a single growth medium and did not study the tolerance value of Acinetobacter sp. to heavy metals in other cultures. Therefore, it can be considered that the obtained tolerance value of heavy metals is not absolute [36].

In laboratory experiments, $\mathrm{C} / \mathrm{N}$ sources were added to the culture medium to evaluate the effect of various nutrients on cell yield by a turbidity measurement, during the same culture time. The result showed that Acinetobacter sp. SCYY-5 could quickly utilize citrate and L-glutamic acid, and exhibit high metabolic activity. It is known that Acinetobacter sp. cannot use carbon sources extensively, while Acinetobacter sp. Y1 isolated by Liu et al. (2015) [37] used citrate and pyruvate during metabolic processes and Acinetobacter johnonii DBP-3 isolated by Li et al. (2013) [38] was also able to utilize carbon sources (sodium citrate $>$ glucose). This is consistent with the preference of the isolates for citrate in this 
study. Moreover, the isolate showed significant differences in nitrogen source utilization. Compared with the control group, there was no good cellular activity during the $50 \mathrm{~h}$ of growth when the inorganic nitrogen source was added. L-glutamic acid, as an organic nitrogen source, provides a mixture of peptides, which can promote bacterial growth to $1.485\left(\mathrm{OD}_{600}\right)$ in $24 \mathrm{~h}$ of growth.

The preliminary degradation study indicated that the oil usually forms a thin layer in the water system, and the degree of oil dispersion partially determined the surface area of the oil that Acinetobacter sp. SCYY-5 could contact [39]. The bacteria were mainly active in the oil-water interface, and the increase in the available boundary area would promote biodegradation $[40,41]$. For bioremediation of oil sludge pollution, some studies have evaluated the ability of bacteria to degrade hydrocarbons. However, most bacteria can only use limited hydrocarbon compounds. For instance, the Geobacillus jurassicus isolated by Nazina et al. (2005) [42] can only grow on C6-C16, and the Acinetobacter sp. BT1A isolated by Acer et al. (2016) [43] is capable of growing on C11-C34. While the Acinetobacter sp. SCYY-5 in this study showed a higher hydrocarbon degradation potential for C9-C34. The degradation efficiency of the isolate reached $69.17 \%$ on the 10 th day of culture. Table 2 shows that it also has a good degradation effect on long-chain alkanes. It is generally believed that these strains can respond to petroleum hydrocarbon stress. Saturated hydrocarbons are degraded efficiently with the degradation of alkanes through terminal oxidation and Finnerty pathway [44]. Figure 6 shows two aerobic pathways of alkane degradation by Acinetobacter, especially for n-alkanes with more than one carbon atom, the most common degradation pathway is the terminal oxidation of alkanes. Microorganisms attack the terminal methyl groups of n-alkanes and generate primary alcohols under the action of oxygenases, which are further oxidized to aldehydes and fatty acids, and enter $\beta$ oxidation [45]. Nonetheless, these biodegradation mechanisms need to be further studied and verified.

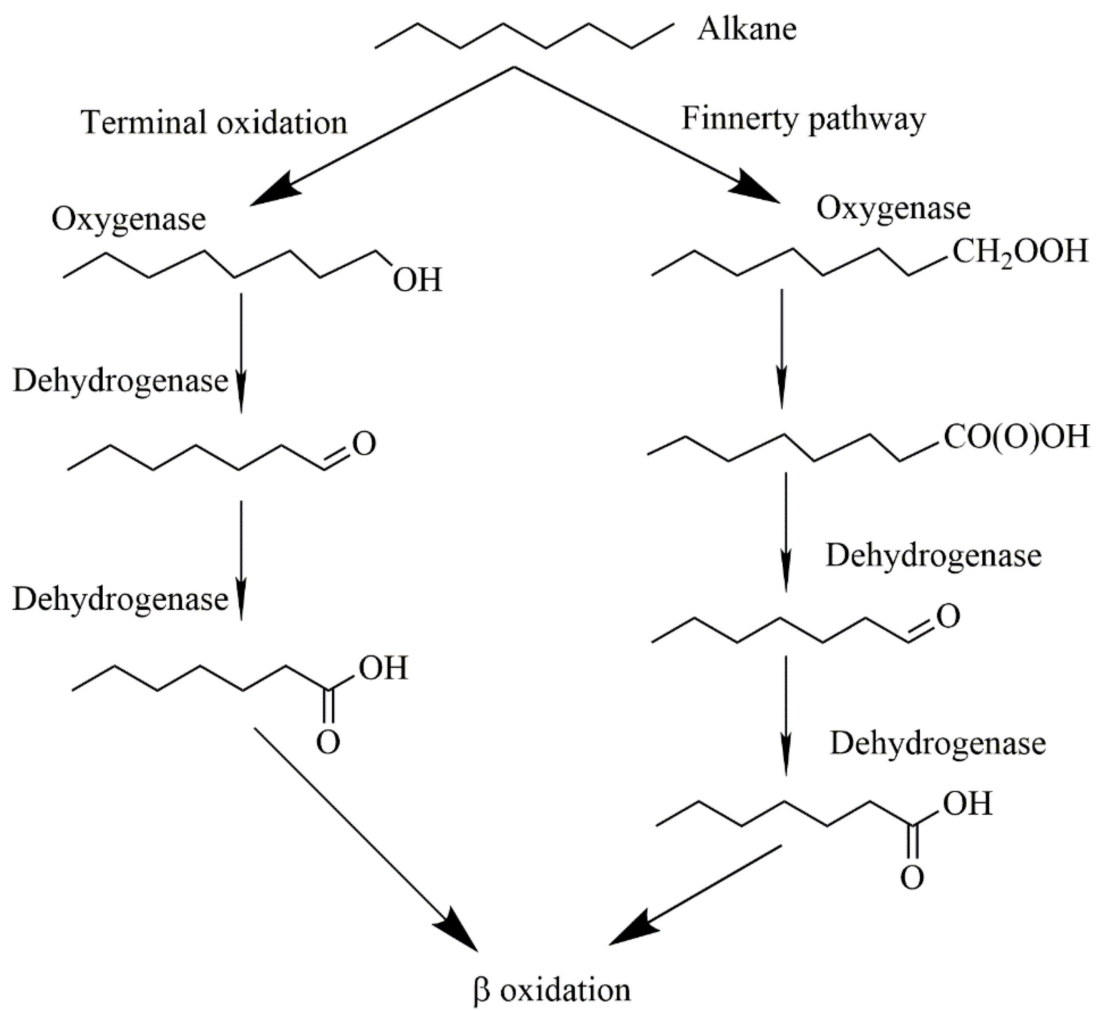

Figure 6. Two aerobic pathways of alkane degradation by Acinetobacter: Terminal oxidation and Finnerty pathway. 
The combination of excessive biological stimuli, such as adding excessive nutrients to polluted environments or changing environmental variables, will also inhibit the growth activity of bacteria $[46,47]$. Therefore, replacing the traditional biodegradation technique with RSM can provide a more effective application to improve bioremediation. RSM used ANOVA to conduct statistical analysis of the model. It analyzed and optimized the relationship between bacteria and multiple environmental variables $(\mathrm{pH}$, temperature, and $\mathrm{NaCl}$ ) to obtain the best response. The results showed that the $R^{2}$ value was 0.8616 and the adjusted $R^{2}$ value was 0.7596 . The high values of $R^{2}$ and adjusted $R^{2}$ reflected the success of the model prediction. The closeness of these two values indicated that the experimental results were compatible with the model [48,49]. In particular, under the optimal growth conditions (temperature $=30.77^{\circ} \mathrm{C}, \mathrm{pH}=8.20$ and $\mathrm{NaCl}=10.12 \mathrm{~g} \mathrm{~L}^{-1}$ ), the degradation efficiency of TPH increased to $79.94 \%$ within 10 days with the addition of complex carbon and nitrogen sources. It is documented that bioremediation strategies with added nutrients often enhance oil degradation significantly [50]. The complex carbon and nitrogen sources could provide a more comprehensive nutritional requirement for bacteria to meet the needs of the co-metabolism matrix during growth or degradation.

\section{Conclusions}

In this study, the SCYY-5 strain that survived in the presence of high concentrations of TPH was isolated. It was identified as Acinetobacter sp. by $16 \mathrm{~S}$ rDNA sequence analysis. Through the 10-day degradation experiment, it was determined that the isolated bacteria had biodegradation ability in oil sludge. TPH removal reached $69.17 \%$ on the 10 th day of culture, which was an effective bacterial degradation. The optimum degradation conditions (temperature $=30.77^{\circ} \mathrm{C}, \mathrm{pH}=8.20$ and $\mathrm{NaCl}=10.12 \mathrm{~g} \mathrm{~L}^{-1}$ ) of TPH were predicted by RSM. Under the optimal conditions, with the addition of citrate and L-glutamic acid, the TPH biodegradation efficiency was improved to $79.94 \%$. The results indicated that optimal strategy is suitable and is greatly significant to bioremediate oil sludge pollution.

Supplementary Materials: The following are available online at https:/ /www.mdpi.com/1660-4 $601 / 18 / 2 / 819 / s 1$, Table S1. The content of the various hydrocarbons in oily sludge before and after the treatment; Figure S1. Diagnostic plots for TPHs removal (a) normal plot of residuals: standardized residuals versus normal probability percentage, and (b) standardized residuals plotted against predicted value.

Author Contributions: Conceptualization: P.R. and R.W.; methodology: Y.C. and R.W.; data analysis: Y.C., L.H., and B.W.; writing-original draft preparation: Y.C.; writing-review and editing: Y.C., X.Z. and R.W.; supervision, funding acquisition, and project administration: P.R., L.Y., S.P., M.R. and R.W. All authors have read and agreed to the published version of the manuscript.

Funding: This research was funded by the Open Project Program of State Key Laboratory of Petroleum Pollution Control (PPC2018017), CNPC Research Institute of Safety and Environmental Technology.

Acknowledgments: This work was supported by the Soil Collaborative Innovation Center in Shanghai University of Engineering Science.

Conflicts of Interest: The authors declared that they have no conflict of interest in this work. The funders had no role in the design of the study; in the collection, analyses, or interpretation of data; in the writing of the manuscript, or in the decision to publish the results.

\section{References}

1. Cameotra, S.S.; Singh, P. Bioremediation of oil sludge using crude biosurfactants. Int. Biodeterior. Biodegrad. 2008, 62, 274-280. [CrossRef]

2. Trindade, P.V.; Sobral, L.G.; Rizzo, A.C.; Leite, S.G.; Soriano, A.U. Bioremediation of a weathered and a recently oil-contaminated soils from Brazil: A comparison study. Chemosphere 2005, 58, 515-522. [CrossRef] [PubMed]

3. Giles, W.R., Jr.; Kriel, K.D.; Stewart, J.R. Characterization and bioremediation of a weathered oil sludge. Environ. Geosci. 2001, 8, 110-122. [CrossRef]

4. Chen, P.; Kan, L.B. Research on the Treatment of Oily Sludge. Adv. Mater. Res. 2013, 671-674, 2746-2749. [CrossRef] 
5. Khan, M.A.I.; Biswasa, B.; Smitha, E.; Naidub, R.; Megharaj, M. Toxicity assessment of fresh and weathered petroleum hydrocarbons in contaminated soil- a review. Chemosphere 2018, 212, 755-767. [CrossRef]

6. Xu, Y.; Lu, M. Bioremediation of crude oil-contaminated soil: Comparison of different biostimulation and bioaugmentation treatments. J. Hazard. Mater. 2010, 183, 395-401. [CrossRef]

7. Kuiper, I.; Lagendijk, E.L.; Bloemberg, G.V.; Lugtenberg, B.J. Rhizoremediation A Beneficial Plant Microbe Interaction. Mol. Plant Microbe Interact. 2004, 17, 6-15. [CrossRef]

8. Xu, J.; Xin, L.; Huang, T.; Chang, K. Enhanced bioremediation of oil contaminated soil by graded modified Fenton oxidation. J. Environ. Sci. 2011, 23, 1873-1879. [CrossRef]

9. Mohanty, G.; Mukherji, S. Biodegradation rate of diesel range $n$-alkanes by bacterial cultures Exiguobacterium aurantiacum and Burkholderia cepacia. Int. Biodeterior. Biodegrad. 2008, 61, 240-250. [CrossRef]

10. Biswal, B.K.; Tiwari, S.N.; Mukherji, S. Biodegradation of oil in oily sludges from steel mills. Bioresour. Technol. 2009, 100, 1700-1703. [CrossRef]

11. Das, K.; Mukherjee, A.K. Crude petroleum-oil biodegradation efficiency of Bacillus subtilis and Pseudomonas aeruginosa strains isolated from a petroleum-oil contaminated soil from North-East India. Bioresour. Technol. 2007, 98, 1339-1345. [CrossRef] [PubMed]

12. Baumann, P.; Doudoroff, M.; Stanier, R.Y. A Study of the Moraxella Group II. Oxidative-negative Species (Genus Acinetobacter). J. Bacteriol. 1968, 95, 1520-1541. [CrossRef] [PubMed]

13. Essien, J.P.; Ebong, G.A.; Asuquo, J.E.; Olajire, A.A. Hydrocarbons contamination and microbial degradation in mangrove sediments of the Niger Delta region (Nigeria). Chem. Ecol. 2012, 28, 421-434. [CrossRef]

14. Oyetibo, G.O.; Ilori, M.O.; Obayori, O.S.; Amund, O.O. Biodegradation of petroleum hydrocarbons in the presence of nickel and cobalt. J. Basic Microbiol. 2013, 53, 917-927. [CrossRef] [PubMed]

15. Elibol, M. Optimization of medium composition for actinorhodin production by Streptomyces coelicolor A3(2) with response surface methodology. Process Biochem. 2004, 39, 1057-1062. [CrossRef]

16. Sharma, S.; Malik, A.; Satya, S. Application of response surface methodology (RSM) for optimization of nutrient supplementation for Cr (VI) removal by Aspergillus lentulus AML05. J. Hazard. Mater. 2009, 164, 1198-1204. [CrossRef] [PubMed]

17. Bezerra, M.A.; Santelli, R.E.; Oliveira, E.P.; Villar, L.S.; Escaleira, L.A. Response surface methodology (RSM) as a tool for optimization in analytical chemistry. Talanta 2008, 76, 965-977. [CrossRef]

18. Shokri, A.; Daraei, P.; Zereshki, S. Water decolorization using waste cooking oil: An optimized green emulsion liquid membrane by RSM. J. Water Process Eng. 2020, 33, 101021. [CrossRef]

19. Rigas, F.; Dritsa, V.; Marchant, R.; Papadopoulou, K.; Avramides, E.J.; Hatzianestis, I. Biodegradation of lindane by Pleurotus ostreatus via central composite design. Environ. Int. 2005, 31, 191-196. [CrossRef]

20. Abdulgader, M.; Yu, Q.J.; Zinatizadeh, A.A.; Williams, P.; Rahimi, Z. Application of response surface methodology (RSM) for process analysis and optimization of milk processing wastewater treatment using multistage flexible fiber biofilm reactor. J. Environ. Chem. Eng. 2020, 8, 103797. [CrossRef]

21. Jiang, Y.; Zhang, Z.; Zhang, X. Co-biodegradation of pyrene and other PAHs by the bacterium Acinetobacter johnsonii. Ecotoxicol. Environ. Saf. 2018, 163, 465-470. [CrossRef] [PubMed]

22. Zhang, Q.; Achal, V.; Xiang, W.N. Identification of Heavy Metal Resistant Bacteria Isolated from Yangtze River, China. Int. J. Agric. Biol. 2014, 16, 619-623. [CrossRef]

23. Zakaria, Z.A.; Zakaria, Z.; Surif, S.; Ahmad, W.A. Hexavalent chromium reduction by Acinetobacter haemolyticus isolated from heavy-metal contaminated wastewater. J. Hazard. Mater. 2007, 146, 30-38. [CrossRef] [PubMed]

24. Moreira, I.S.; Amorim, C.L.; Carvalho, M.F.; Castro, P.M. Degradation of difluorobenzenes by the wild strain Labrys portucalensis. Biodegradation 2012, 23, 653-662. [CrossRef] [PubMed]

25. Jiang, Y.; Qi, H.; Zhang, X.M. Co-biodegradation of anthracene and naphthalene by the bacterium Acinetobacter johnsonii. J. Environ. Sci. Health Part A Toxic Hazard. Subst. Environ. Eng. 2018, 53, 448-456. [CrossRef] [PubMed]

26. Onur, G.; Yilmaz, F.; Icgen, B. Diesel Oil Degradation Potential of a Bacterium Inhabiting Petroleum Hydrocarbon Contaminated Surface Waters and Characterization of Its Emulsification Ability. J. Surfactants Deterg. 2015, 18, 707-717. [CrossRef]

27. Sanusi, S.N.A.; Halmi, M.I.E.; Abdullah, S.R.S.; Hassan, H.A.; Hamzah, F.M.; Idris, M. Comparative process optimization of pilotscale total petroleum hydrocarbon (TPH) degradation by Paspalum scrobiculatum L. Hack using response surface methodology (RSM) and artificial neural networks (ANNs). Ecol. Eng. 2016, 97, 524-534. [CrossRef]

28. Prakash Maran, J.; Manikandan, S.; Thirugnanasambandham, K.; Vigna Nivetha, C.; Dinesh, R. Box-Behnken design based statistical modeling for ultrasound-assisted extraction of corn silk polysaccharide. Carbohydr. Polym. 2013, 92, 604-611. [CrossRef]

29. Al-Baldawi, I.A.; Sheikh Abdullah, S.R.; Abu Hasan, H.; Suja, F.; Anuar, N.; Mushrifah, I. Optimized conditions for phytoremediation of diesel by Scirpus grossus in horizontal subsurface flow constructed wetlands (HSFCWs) using response surface methodology. J. Environ. Manage. 2014, 140, 152-159. [CrossRef]

30. Hassanshahian, M.; Emtiazi, G.; Cappello, S. Isolation and characterization of crude-oil-degrading bacteria from the Persian Gulf and the Caspian Sea. Mar. Pollut. Bull. 2012, 64, 7-12. [CrossRef]

31. Zhang, Y.; Gao, W.; Lin, F.; Han, B.; He, C.; Li, Q.; Gao, X.; Cui, Z.; Sun, C.; Zheng, L. Study on immobilization of marine oil-degrading bacteria by carrier of algae materials. World J. Microbiol. Biotechnol. 2018, 34, 70. [CrossRef] [PubMed] 
32. Chen, Y.; Li, C.; Zhou, Z.; Wen, J.; You, X.; Mao, Y.; Lu, C.; Huo, G.; Jia, X. Enhanced biodegradation of alkane hydrocarbons and crude oil by mixed strains and bacterial community analysis. Appl. Biochem. Biotechnol. 2014, 172, 3433-3447. [CrossRef] [PubMed]

33. Liu, W.; Luo, Y.; Teng, Y.; Li, Z.; Ma, L.Q. Bioremediation of oily sludge-contaminated soil by stimulating indigenous microbes. Environ. Geochem. Health 2010, 32, 23-29. [CrossRef] [PubMed]

34. Sood, N.; Patle, S.; Lal, B. Bioremediation of acidic oily sludge-contaminated soil by the novel yeast strain Candida digboiensis TERI ASN6. Environ. Sci. Pollut. Res. 2010, 17, 603-610. [CrossRef] [PubMed]

35. Cai, X.; Zheng, X.; Zhang, D.; Iqbal, W.; Liu, C.; Yang, B.; Zhao, X.; Lu, X.; Mao, Y. Microbial characterization of heavy metal resistant bacterial strains isolated from an electroplating wastewater treatment plant. Ecotoxicol. Environ. Saf. 2019, 181, 472-480. [CrossRef] [PubMed]

36. Thorneley, R.N.F. Metal ions and bacteria. Trends Biotechnol. 1990, 8, 298-299. [CrossRef]

37. Liu, Y.; Hu, T.; Song, Y.; Chen, H.; Lv, Y. Heterotrophic nitrogen removal by Acinetobacter sp. Y1 isolated from coke plant wastewater. J. Biosci. Bioeng. 2015, 120, 549-554. [CrossRef] [PubMed]

38. Li, M.T.; Liu, J.H.; Zhao, S.J.; Wang, Z.X.; Hao, L.L. The characteristics of nitrate removal by the psychrotolerant denitrifying bacterium Acinetobacter johnonii DBP-3, isolated from a low-temperature eutrophic body of water. J. Environ. Sci. Health Part B 2013, 48, 885-892. [CrossRef]

39. Overholt, W.A.; Marks, K.P.; Romero, I.C.; Hollander, D.J.; Snell, T.W.; Kostka, J.E. Hydrocarbon-Degrading Bacteria Exhibit a Species-Specific Response to Dispersed Oil while Moderating Ecotoxicity. Appl. Environ. Microbiol. 2016, 82, 518-527. [CrossRef]

40. Gatellier, C.R.; Oudin, J.L.; Fusey, P.; Lacaze, J.C.; Priou, M.L. Experimental Ecosystems to Measure Fate of Oil Spills Dispersed by Surface Active Products. Int. Oil Spill Conf. Proc. 1973, 497-504. [CrossRef]

41. Gutnick, D.L.; Rosenberg, E. Oil tankers and pollution a microbiological approach. Annu. Rev. Microbiol. 1977, 31, 379-396. [CrossRef] [PubMed]

42. Nazina, T.N.; Sokolova, D.; Grigoryan, A.A.; Shestakova, N.M.; Mikhailova, E.M.; Poltaraus, A.B.; Tourova, T.P.; Lysenko, A.M.; Osipov, G.A.; Belyaev, S.S. Geobacillus jurassicus sp. nov., a new thermophilic bacterium isolated from a high-temperature petroleum reservoir, and the validation of the Geobacillus species. Syst. Appl. Microbiol. 2005, 28, 43-53. [CrossRef] [PubMed]

43. Acer, Ö.; Güven, K.; Bekler, F.M.; Gül-Güven, R. Isolation and characterization of long-chain alkane-degrading Acinetobacter sp. BT1A from oil-contaminated soil in Diyarbakır, in the Southeast of Turkey. Biorem. J. 2016, 20, 80-87. [CrossRef]

44. Sakai, Y.; Maeng, J.H. A non-conventional dissimilation pathway for long chain n-alkanes in Acinetobacter sp. M-1 that starts with a dioxygenase reaction. J. Ferment. Bioeng. 1996, 81, 286-291. [CrossRef]

45. Asperger, O.; Kleber, H.P. Metabolism of Alkanes by Acinetobacter. In The Biology of Acinetobacter; Springer: New York, NY, USA, 1991; pp. 323-350. [CrossRef]

46. Walworth, J.; Pond, A.; Snape, I.; Rayner, J.; Ferguson, S.; Harvey, P. Nitrogen requirements for maximizing petroleum bioremediation in a sub-Antarctic soil. Cold Reg. Sci. Technol. 2007, 48, 84-91. [CrossRef]

47. Namkoonga, W.; Hwangb, E.Y.; Parka, J.S.; Choic, J.Y. Bioremediation of diesel-contaminated soil with composting. Environ. Pollut. 2002, 119. [CrossRef]

48. Gunst, R.F. Response Surface Methodology: Process and Product Optimization Using Designed Experiments. Technometrics 1996, 38, 284-286. [CrossRef]

49. Sabour, M.R.; Amiri, A. Comparative study of ANN and RSM for simultaneous optimization of multiple targets in Fenton treatment of landfill leachate. Waste Manag. 2017, 65, 54-62. [CrossRef]

50. Chen, J.; Huang, P.T.; Zhang, K.Y.; Ding, F.R. Isolation of biosurfactant producers, optimization and properties of biosurfactant produced by Acinetobacter sp. from petroleum-contaminated soil. J. Appl. Microbiol. 2012, 112, 660-671. [CrossRef] 